\title{
Potential of Acclimated Earthworm (Eisenia Andrei) for Detoxification of Olive Mill Wastewater
}

\author{
Barhoum Kharbouch ${ }^{1.2 *}$, Hicham Lakhtar', Sandrine Amat ${ }^{2}$, Sevastianos Roussos ${ }^{2}$, Nathalie Dupuy ${ }^{2}$, \\ Abdelhamid El Mousadik ${ }^{3}$ \\ ${ }^{1}$ Laboratory of Microbial Biotechnology and Crop Protection, Ibn Zohr University, Faculty of Sciences, BP 8106 City Dakhla \\ Agadir, Morocco. \\ ${ }^{2}$ Aix Marseille Univ, CNRS, IRD, Avignon university IMBE, UMR 7263, 13397 Marseille, France. \\ ${ }^{3}$ Laboratory of biotechnology and valorization of natural resources, University of Ibn Zohr, faculty of sciences, BP 8106 City \\ Dakhla Agadir, Morocco.
}

How to cite this paper: Barhoum Kharbouch, Hicham Lakhtar, Sandrine Amat, Sevastianos Roussos, Nathalie Dupuy, and Abdelhamid El Mousadik.

(2020) Potential of Acclimated Earthworm (Eisenia Andrei) for Detoxification of Olive Mill Wastewater. International Journal of the Science of Food and Agriculture, 4(2), 148-155.

DOI: $10.26855 /$ ijfsa.2020.06.006

Received: November 22, 2019

Accepted: March 22, 2020

Published: April 24, 2020

*Corresponding author: Barhoum Kharbouch, Laboratory of Microbial Biotechnology and Crop Protection, Ibn Zohr University, Faculty of Sciences, BP 8106 City Dakhla Agadir, Morocco; Aix Marseille Univ, CNRS, IRD, Avignon university IMBE, UMR 7263, 13397 Marseille, France.

Email:

Kharbouch-barhoum@hotmail.fr

\begin{abstract}
The present study was conducted to evaluate the potential of acclimated and unacclimated earthworm (Eisenia andrei) for decomposition and detoxification of olive mill wastewater (OMWW). Although, they stimulate biological reactions at low concentrations, OMWW are toxic to earthworms and microorganisms at moderate concentrations and can cause negative effects on the vermicomposting processes. After two months of laboratory vermicomposting, the growth rate $\left(21.83 \pm 0.01 \mathrm{mg} \mathrm{worm}^{-1}\right.$ day $\left.^{-1}\right)$ of earthworms and phenols reduction $(72 \%)$, were higher with acclimated earthworms. However, unacclimated earthworms showed lower growth rate $\left(4.67 \pm 0.01 \mathrm{mg}\right.$ worm $\left.{ }^{-1} \mathrm{day}^{-1}\right)$ and phenols reduction $(41 \%)$. Moreover, the vermicompost produced with acclimated earthworm is characterized by alkaline $\mathrm{pH}$ (9.9), optimal electrical conductivity (78.20 dS $\mathrm{cm}^{-1}$ ), optimal $\mathrm{C} / \mathrm{N}$ ratios $(17.40-18.00)$ and an increase in total nitrogen $(1.7-2.0 \%)$. The data reveal that the acclimated earthworms are well adapted in the moderate OMWW concentration and their utilization in vermicomposting process could be a promising alternative for OMWW detoxification. Additionally, vermicomposting can be a suitable technology for olive mill wastewater treatment.
\end{abstract}

\section{Keywords}

Olive Pomace, Olive Mill Wastewater, Vermicomposting, Eisenia Andrei, Total Phenols, Enzymatic Activities, Acclimatization

\section{Introduction}

Olive oil production causes serious environmental problems due the production of high quantity of by-products, namely olive pomace (OP), olive mill wastewater (OMWW) (from three-phase systems), and two-phase olive mill waste (TPOMW) (from two-phase systems) during short production season [1]. Worldwide annual production of OMWW is estimated at $3 \times 10^{6} \mathrm{~m}^{3}$ [2], with an organic load equivalent to about 22 million people per year [1]. Morocco is the six olive oil-producing countries $(130,000 \mathrm{t})$ [3]. However, this activity produces a huge quantity of OP and olive OMWW causing serious environmental problems. Indeed, OMWW present a major environmental challenge due to their highly toxic organic loads and their high chemical oxygen demand (COD) 
$\left(110 \mathrm{~g} \mathrm{~L}^{-1}\right)$ [4]. Nowadays, recycling of solid olive residues is generally limited to their use as a cheap and local source of fuel for ovens and water heating [5]. In Morocco, OMWW was simply dumped directly into the sewage system, kept in evaporation lagoons or just spread on land, what frequently results in an important environmental pollution [6]. Consequently, a direct application of OMWW in soil affects its infiltration capacity, with negatively affect groundwater quality [7]. The difficulty of treating OMWW is due to their high levels of recalcitrant organic compounds [8], and to technical constraints related to seasonal production and to the scattering of the olive-mill units over the whole territory.

Given this situation, several chemical, physical and biological techniques were developed to treat and recycle OMWW. Despite the efficiency of these processes, their high cost is the main drawback to their industrial application (example in Morocco) [9]. Vermicomposting is a cost-effective alternative and a rapid biotechnological process to convert organic substances into a stabilized humus-like product [10]. Furthermore, some species of earthworms are able to consume a wide range of organic wastes from sewage sludge, animal wastes, and agricultural residues, domestic and industrial wastes [11]. The viability of using vermicomposting to stabilize olive wastes was proved. OMWW can support reproduction and growth of earthworms, especially when mixed with other nitrogen-rich wastes [12]. The subsequent application of vermicompost to soil demonstrates that it can be used as organic amendments to promote plant growth and regenerate degraded soils [12]. In fact, vermicompost was considered as an excellent organic amendment because it contains plant growth hormones and a larger microbial population as well as it tends to contain more nutrients without negative impact on the environment than traditional compost [13].

In the literature, acclimation of earthworms prior to vermicomposting has never been studied. The aim of the present study was to test the effect of acclimatization on potential of earthworms for detoxification of OMWW at laboratory vermicomposting scale.

\section{Material and Methods}

\subsection{Earthworms and collection of olive by-products}

Earthworms (with clitellum) belonging to the Eisenia species [14] were used in this work. This specie was chosen thanks to its high activity, a short time of growth, high rate of reproduction and be handled easily [15].

Olive by-products (OMWW and OP) (Table 1) were collected from a three-phase centrifugation system in Oulad Teïma (30 23 '40.8 "North, 9 $9^{\circ} 12^{\prime}$ 32.3" West) province of Agadir, Morocco. Horse Manure (HM) was provided by a horse farm (Agadir). Wheat Straw (WS) obtained from the same farm was added as bulking agent. All substrates were air-dried in a greenhouse and stored before launching the vermicomposting experiments.

\subsection{Experimental design}

Two groups of earthworms (Eisenia andrei) have been acclimated differently. The first group of earthworms has been acclimated to the OMWW; by raising them in a mixture composed of $60 \%$ OP, $30 \% \mathrm{HM}$ and $10 \%$ WS soaked with $10 \%$ OMWW for six months before our experimentation. The second group of earthworms was raised in the same mixture without OMWW. To initiate our experiment, a mixture of OP $(60 \% \mathrm{D} . \mathrm{W}), \mathrm{HM}(30 \%$ D.W) and WS (10\% D.W) was prepared, then soaked by $80 \%$ of OMWW and pre-composted for one month. The laboratory vermicomposting study was carried out in a $2.5 \mathrm{~L}$ plastic box. To test the effect of acclimatation, $1 \mathrm{~kg}$ of pre-composted mixture was inoculated with 5 adult and acclimated earthworms [16]. Another, $1 \mathrm{~kg}$ of pre-composted mixture was inoculated with 5 adult and unacclimated earthworms. Each treatment was run in triplicate.

The change in individual biomass of earthworms was measured every 10 days in each experiment. Earthworms were separated from the substrate material by hand sorting, after which worms were washed in tap water to remove adhering material from their body, and subsequently weighed on a live weight basis. No correction for gut content was applied to any of the data. Then all measured earthworms were returned to the container. The following observations were made during experimentations: the maximum biomass achieved, net biomass gain, maximum growth rate $\left(\mathrm{mg}\right.$ worm ${ }^{-1}$ day $\left.^{-1}\right)$.

Samples were handily homogenized and collected from each experiment every ten days during two months and they were air-dried and stored for further analysis; $\mathrm{pH}$, electrical conductivity, carbon/nitrogen $(\mathrm{C} / \mathrm{N})$ ratio and total phenol content. The moisture level of each mixture was maintained about $75-80 \%$ throughout the study 
period by periodic sprinkling of adequate quantity of water.

\subsection{Statistical analysis}

The data analyses were carried using STATISTICA, version 6, and one-way ANOVA was used to analyze the differences between treatments. A Newman-Keuls test was also performed to identify the homogeneous type of the data sets among different treatments for different biological parameters of earthworms and chemical and biochemical parameters (i.e., $\mathrm{pH}, \mathrm{EC}$, phenol and $\mathrm{C} / \mathrm{N}$ ratio) in each experiment.

\section{Results and Discussion}

\subsection{Biomass and Growth Rate of Earthworms}

As shown in Figure 1, the biomass of acclimated earthworms increased significantly from the beginning of the laboratory vermicomposting and their maximum biomass (ANOVA, $\mathrm{F}=11.05, \mathrm{P}<0.05$ ) reached was $3.58 \mathrm{~g} \pm 0.3$ after 40days. After this, a slight decrease of biomass was observed to reach $3.44 \pm 0.24 \mathrm{~g}$. However, unacclimated earthworms presented a decrease in average biomass during10 days of laboratory vermicomposting and a slight increase in the average biomass was recorded to reach $2.45 \pm 0.13 \mathrm{~g}$ at the end of the experiment.

The growth rate expressed in milligrams of biomass acquired per earthworm per day was considered as a very good indicator for comparing earthworm growth in different substrates [17]. The maximum growth rate was achieved in mixture with acclimated earthworms $\left(21.83 \pm 0.02 \mathrm{mg} \mathrm{worm}^{-1}\right.$ day $\left.^{-1}\right)$ (Fig. 2). However, the growth rate of unacclimated earthworms $\left(4.67 \pm 0.03 \mathrm{mg}\right.$ worm $\left.{ }^{-1} \mathrm{day}^{-1}\right)$ was 4.67 lower than recorded with acclimated earthworms. Ganesh et al. [18] deduce that raw materials with high phenols fraction and lignin concentration (such as OP and OMWW) are not well adequate for the growth and the development of most species of earthworms. In this study, the difference in growth rate between earthworms could be attributed to the effect of the acclimatization of earthworms to OMWW. El Hajjoujiet al. [6] reported antimicrobial and toxic effects of OMWW. Suthar conclude that microbial activity is essential for organic matter degradation by earthworms [19].

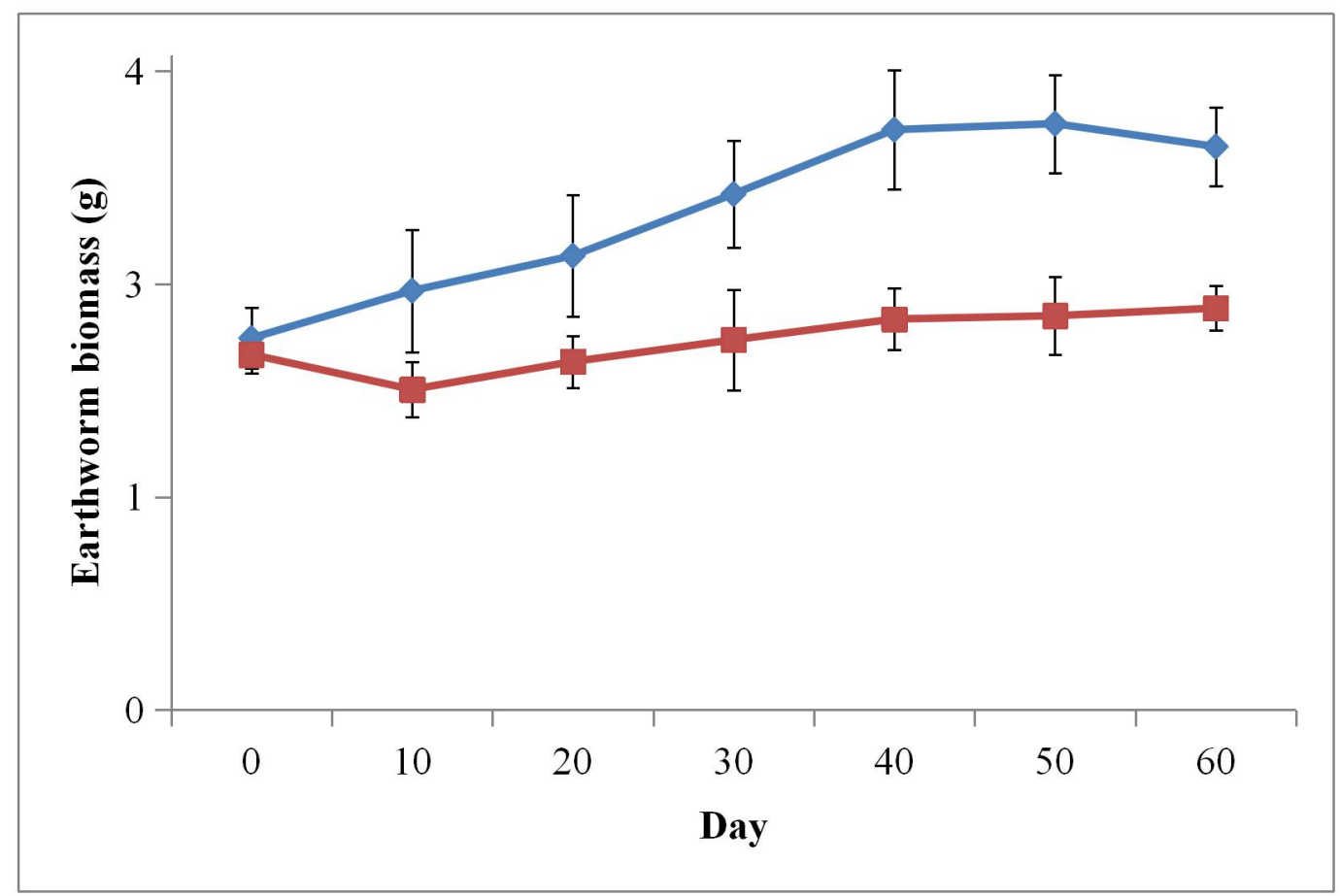

Figure 1: Biomass changes of acclimated $\left(-\right.$ ) and unacclimated $\left(-\frac{-}{-}\right.$ ) earthworms during vermicomposting experiments. Vertical bars indicate standard deviation. 


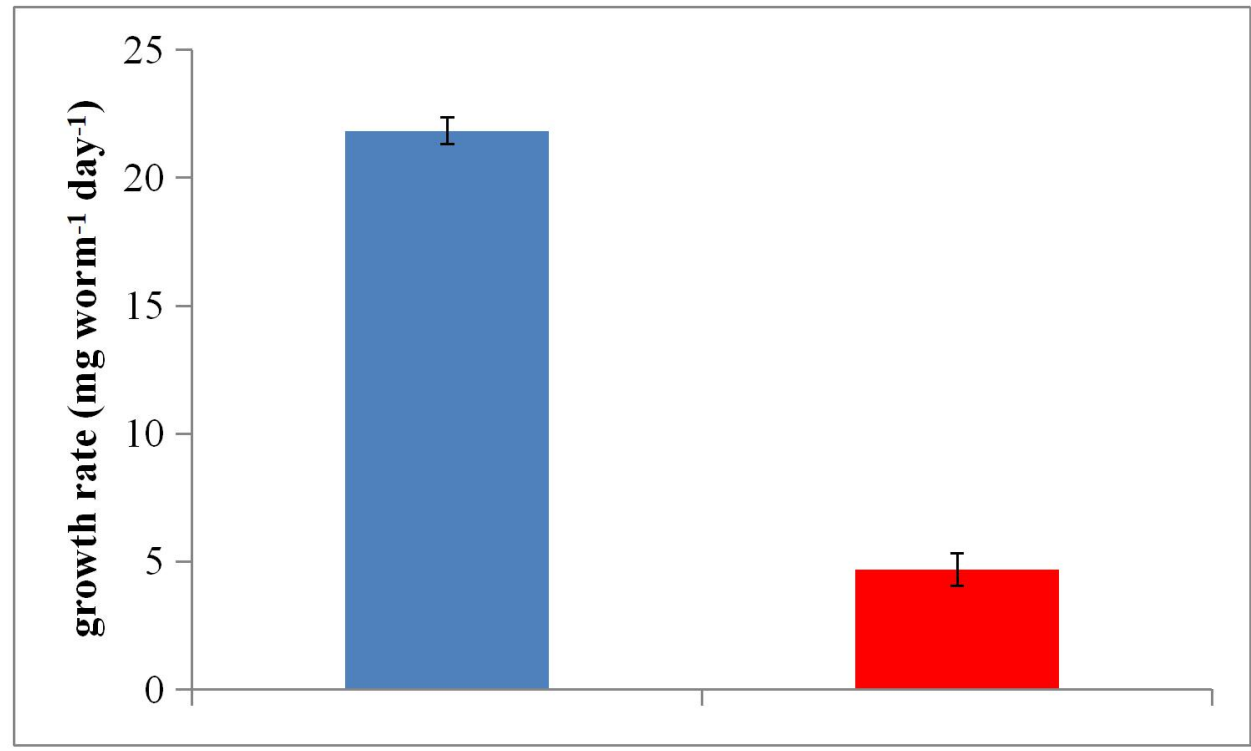

Figure 2: Growth rate of acclimated $(-)$ and unacclimated ( ${ }^{-}$) earthworms. Vertical bars indicate standard deviation.

\section{2. $\mathrm{pH}$}

$\mathrm{pH}$ was a good indicator of bio-oxidation progress, microbial development as well as development of earthworm in vermicomposting process [17]. In fact, earthworms can survive in a pH range of 5 to 9 . OMWW are acid $\mathrm{pH}$ [20], which caused serious environmental problems. Earthworms cannot support OMWW toxicity, for this reason, pre-composting was carried out one month prior to vermicomposting process. During vermicomposting period, a progressive increase of $\mathrm{pH}$ was observed in two mixtures, reaching a maximum of 9.9with acclimated earthworms (Table 2). At the end of vermicomposting, no significant difference was detected between experiments concerning this parameter (ANOVA, Newman-Keuls test, $\mathrm{P}>0.05$ ). The change of $\mathrm{pH}$ is strongly dependent on the starting materials. For example, no significant changes of $\mathrm{pH}$ are reported for these substrates: manures [21] and sorghum bagasse [22]. However, Benitez et al. [23] and Tiquia and Tam [24] reported a decrease of $\mathrm{pH}$ for sewage sludge and pig manure respectively, while increases were monitored in pruning wastes [25] rice straw and greenhouse waste [26]. Dias et al. [27] conclude that $\mathrm{pH}$ changes was affected by several factors: initial decarboxylation of organic acids, formation of ammonium from protein degradation, mineralization of nitrogen followed by nitrification $\left(\mathrm{NH}_{4}{ }^{+}\right.$is transformed into $\left.\mathrm{NO}_{3}{ }^{-}\right)$and production of humic acids. During vermicomposting process, the mineralization of proteins, amino acids and peptides lead to the release of ammonium or volatile ammonia and contribute to the increase of $\mathrm{pH}$. Tognettiet al. [28] reported that this increase could be due to the degradation of short-chain fatty acids and intensive nitrogen mineralization by microorganisms. Plaza et al. [29] noted an increase of $\mathrm{pH}$ (6 to 8) at the end of vermicomposting olive pomace added to horse manure. Asses et al. [30] reported same result during co-composting of sewage sludge with olive mill wastes or green residues. Additionally, earthworms did not affect the $\mathrm{pH}$ of organic substrates but they secrete intestinal calcium and eliminate $\mathrm{NH}_{4}^{-}-\mathrm{N}$ to maintain a neutral $\mathrm{pH}$ in their digestive tract [31].

\subsection{Electrical Conductivity (EC)}

Electrical conductivity (EC) of feed was a limiting factor for survival and growth of earthworms [32]. Mitchell [33] explained that earthworms were unable to survive in cattle solids with electrical conductivity of $5.0 \mathrm{dS} \mathrm{m}^{-1}$. In addition, OMWW have negative effects on the soil because of its high salinity, low $\mathrm{pH}$ and the presence of toxic substances. Soluble salts, as estimated by electrical conductivity determination, are generally fairly high throughout the vermicomposting process, with initial values in the range of $229.4 \mathrm{mS} \mathrm{cm}{ }^{-1}$. Electrical conductivity (EC) decreased in two experiments to reach values between 76.2-129.4 mS cm ${ }^{-1}$ with acclimated and unacclimated earthworms respectively. The final values are significant (ANOVA, Newman-Keuls test $\mathrm{F}=813.62$, $\mathrm{P}<0.05$ ) (Table 2). Indeed, the maximum reduction of EC varied between $43 \%-65 \%$ with acclimated and unacclimated earthworms respectively. The decrease in EC during the vermicomposting process can be attributed 
to the drop in soluble ion concentrations, because soluble ions are leached due to the irrigation of beds during the vermicomposting process. Soluble ion was immobilized by the prolific microorganisms or earthworms, or they are precipitated in the form of non-soluble salts [34], representing the biotransformation of waste mixture into more stabilized form of vermicompost [35].

Table 1: chemical properties of initial organic waste used for vermicomposting. Mean of three replicates \pm standard deviation.

\begin{tabular}{cccccc}
\hline Substrate & $\mathrm{N}(\%)$ & $\mathrm{C}(\%)$ & $\mathrm{C} / \mathrm{N}$ & $\mathrm{pH}$ & $\mathrm{Phenols} \mathrm{g} \mathrm{L}^{-1}$ \\
\hline Olive pomace & $1.07 \pm 0.26$ & $50.86 \pm 0.10$ & $49.53 \pm 1.17$ & $6.4 \pm 1.3$ & $0.21 \pm 0.03$ \\
OMWW & $0.97 \pm 0.05$ & $43.69 \pm 1.58$ & $45.32 \pm 2.71$ & $4.6 \pm 1.1$ & $5.62 \pm 0.11$ \\
Horse manure & $1.28 \pm 0.23$ & $27.26 \pm 1.23$ & $21.31 \pm 1.19$ & $8.8 \pm 1.2$ & - \\
Wheat straw & $0.38 \pm 0.11$ & $41.77 \pm 1.81$ & $107.95 \pm 3.13$ & $7.2 \pm 0.5$ & - \\
\hline
\end{tabular}

Table 2: Changes in physicochemical characteristics mixtures with different groups of earthworms. Mean of three replicates \pm standard deviation.

\begin{tabular}{|c|c|c|c|c|c|c|}
\hline Day & N (\%) & $\mathrm{C}(\%)$ & O.M\% & $\mathrm{C} / \mathrm{N}$ ratio & $\mathrm{pH}$ & $\mathrm{EC} \mathrm{mS} \mathrm{cm}{ }^{-1}$ \\
\hline \multicolumn{7}{|c|}{ Acclimated } \\
\hline 0 & $1.7 \pm 0.06^{\mathrm{a}}$ & $41.9 \pm 0.07^{\mathrm{a}}$ & $72.1 \pm 0.17^{\mathrm{a}}$ & $25.3 \pm 0.67^{\mathrm{a}}$ & $9.5 \pm 0.27^{\mathrm{a}}$ & $229.4 \pm 1.16^{\mathrm{a}}$ \\
\hline 10 & $1.7 \pm 0.09^{\mathrm{a}}$ & $39.7 \pm 0.07^{\mathrm{a}}$ & $68.3 \pm 0.17^{\mathrm{a}}$ & $23.8 \pm 0.94^{a . b}$ & $9.6 \pm 0.13^{\mathrm{a}}$ & $185.2 \pm 5.05^{\mathrm{b}}$ \\
\hline 20 & $1.8 \pm 0.10^{\mathrm{a} . \mathrm{b}}$ & $41.1 \pm 0.06^{\mathrm{a}}$ & $70.7 \pm 0.14^{\mathrm{a}}$ & $23.3 \pm 0.88^{\text {b.c }}$ & $9.7 \pm 0.02^{\mathrm{a}}$ & $148.0 \pm 1.78^{c}$ \\
\hline 30 & $1.6 \pm 0.06^{\mathrm{a} . \mathrm{b}}$ & $36.7 \pm 0.09^{\mathrm{a}}$ & $63.1 \pm 0.20^{\mathrm{a}}$ & $22.6 \pm 0.58^{b . c}$ & $9.8 \pm 0.01^{\mathrm{a}}$ & $137.3 \pm 2.44^{\mathrm{d}}$ \\
\hline 40 & $1.8 \pm 0.06^{\mathrm{a} . \mathrm{b}}$ & $37.1 \pm 0.01^{\mathrm{a}}$ & $63.8 \pm 0.02^{\mathrm{a}}$ & $20.4 \pm 0.49^{\mathrm{d}}$ & $9.8 \pm 0.02^{\mathrm{a}}$ & $122.3 \pm 2.89^{\mathrm{e}}$ \\
\hline 50 & $2.0 \pm 0.01^{\mathrm{c}}$ & $39.1 \pm 0.05^{\mathrm{a}}$ & $67.2 \pm 0.12^{\mathrm{a}}$ & $19.7 \pm 0.11^{\mathrm{d}}$ & $9.8 \pm 0.01^{\mathrm{a}}$ & $108.0 \pm 4.89^{f}$ \\
\hline 60 & $2.1 \pm 0.05^{\mathrm{c}}$ & $36.1 \pm 0.08^{\mathrm{a}}$ & $62.0 \pm 0.19^{\mathrm{a}}$ & $17.4 \pm 0.28^{\mathrm{e}}$ & $9.9 \pm 0.05^{\mathrm{a}}$ & $78.2 \pm 2.00^{\mathrm{g}}$ \\
\hline \multicolumn{7}{|c|}{ Unacclimated } \\
\hline 0 & $1.7 \pm 0.06^{\mathrm{a}}$ & $41.9 \pm 0.10^{\mathrm{a}}$ & $72.1 \pm 0.11^{\mathrm{a}}$ & $25.3 \pm 0.67^{\mathrm{a}}$ & $9.5 \pm 0.27^{\mathrm{a}}$ & $229.4 \pm 1.16^{\mathrm{a}}$ \\
\hline 10 & $1.6 \pm 0.06^{\mathrm{a} . \mathrm{b}}$ & $39.4 \pm 0.12^{\mathrm{b}}$ & $67.7 \pm 0.15^{\mathrm{b}}$ & $25.1 \pm 0.67^{\mathrm{a}}$ & $9.6 \pm 0.13^{\mathrm{a}}$ & $195.8 \pm 4.10^{\mathrm{b}}$ \\
\hline 20 & $1.5 \pm 0.06^{\mathrm{b}}$ & $36.8 \pm 0.06^{\mathrm{c}}$ & $63.3 \pm 0.08^{c}$ & $24.9 \pm 0.76^{\mathrm{a}}$ & $9.7 \pm 0.08^{\mathrm{a}}$ & $177.5 \pm 1.87^{\mathrm{c}}$ \\
\hline 30 & $1.6 \pm 0.06^{\mathrm{a} . \mathrm{b}}$ & $39.8 \pm 0.12^{\mathrm{b}}$ & $68.4 \pm 0.15^{\mathrm{b}}$ & $24.8 \pm 0.73^{\mathrm{a}}$ & $9.8 \pm 0.05^{\mathrm{a}}$ & $156.1 \pm 4.26^{\mathrm{d}}$ \\
\hline 40 & $1.5 \pm 0.06^{b}$ & $35.3 \pm 0.12^{\mathrm{d}}$ & $60.6 \pm 0.15^{\mathrm{d}}$ & $24.2 \pm 0.78^{\mathrm{a}}$ & $9.8 \pm 0.04^{\mathrm{a}}$ & $140.3 \pm 1.77^{\mathrm{e}}$ \\
\hline 50 & $1.7 \pm 0.06^{\mathrm{a} . \mathrm{b}}$ & $34.3 \pm 1.10^{\mathrm{e}}$ & $58.9 \pm 1.30^{\mathrm{e}}$ & $19.9 \pm 0.94^{\mathrm{b}}$ & $9.9 \pm 0.02^{\mathrm{a}}$ & $131.4 \pm 4.30^{\mathrm{f}}$ \\
\hline 60 & $1.9 \pm 0.10^{\mathrm{c}}$ & $34.3 \pm 1.10^{\mathrm{e}}$ & $58.9 \pm 1.30^{\mathrm{e}}$ & $18.0 \pm 0.67^{b}$ & $9.9 \pm 0.08^{\mathrm{a}}$ & $129.4 \pm 1.19^{\mathrm{f}}$ \\
\hline
\end{tabular}

*In each column, mean values followed by different letters are statistically different (ANOVA; Newman-Keuls t-test).

\subsection{Carbon/Nitrogen ratio $(\mathrm{C} / \mathrm{N})$}

Carbon/ nitrogen ratio $(\mathrm{C} / \mathrm{N})$ was an important parameter to evaluate vermicompost maturity. Indeed, this ratio is one of the most important factors affecting vermicomposting process and the properties of the final product [35]. $\mathrm{C} / \mathrm{N}$ ratio depends on the optimal physicochemical characteristics of the starting substrate, with an optimum ratio between 30 and 35 [36]. This value is confirmed and qualified by other authors [35- 37]. Golueke [38] reported that ideal initial $\mathrm{C} / \mathrm{N}$ ratio for vermicomposting is 30 . In the presence of woody substrates (wheat straw example) this ratio increases to values between 35 and 40, as a large proportion of carbon is not readily available to microorganisms. In this study, the initial $\mathrm{C} / \mathrm{N}$ ratio was 35 . After one of pre-composting $\mathrm{C} / \mathrm{N}$ ratio decreased to 25 , which is an optimal ratio for development and reproduction of earthworms [39] (Table 2).

After two months of vermicomposting, $\mathrm{C} / \mathrm{N}$ ratio decreased gradually in both experiments starting from 25 and reaching values around 18 and 23 with acclimated earthworms and unacclimated earthworms respectively. These values are consistent with well-stabilized vermicompost that would not alter the microbial equilibrium when 
applied to soil [40]. Grigatti et al. [41] attributed the decrease of $\mathrm{C} / \mathrm{N}$ ratio during vermicomposting process to mineralization of organic matter by microorganisms. Moreover, Parkin and Berry [42] confirmed that combined action of earthworms and microorganisms provoked mineralization and transformation of carbon compounds to simple and available forms consequently decrease $\mathrm{C} / \mathrm{N}$ ratio.

\subsection{Phenols}

The aim of this work was to test effect of acclimatization of earthworms on their potential for OMWW detoxification. Ganesh et al. [18] noted that raw materials with high phenols fraction and lignin concentration (such as OP and OMWW) are not well adequate for growth and development of most species of earthworms. Besides, the chemical composition of the feed substrate has an important role in feed rate of earthworms [43]. Indeed, according to Figure 3, acclimated earthworms showed highest reduction of phenol concentration (72\%), indicating that acclimatization of earthworms affect positively the adaptive potential of earthworms to OMWW and well accept their culture medium. Galliou et al. [44] obtained reduction of $75 \%$ phenol compounds in OMWW by combining solar greenhouse drying and composting. Zenjari and Nejmeddine [7] attributed the decrease of phenol concentration to microbial bioconversion of phenolic compounds and their interaction with secondary metabolites, contributing to the biosynthesis of humic substances. However, experiment with unacclimated earthworms did not lead to a significant reduction in the phenols concentration (41\%). These results demonstrate the positive effect of the acclimatization of earthworms towards OMWW in order to obtain a high rate of detoxification. In another study done by Madani et al. [45], using Fenton oxidation processes was obtained $98.6 \%$ in phenol reduction, but they found that $\mathrm{pH}$ affect the efficiencies of Fenton process.

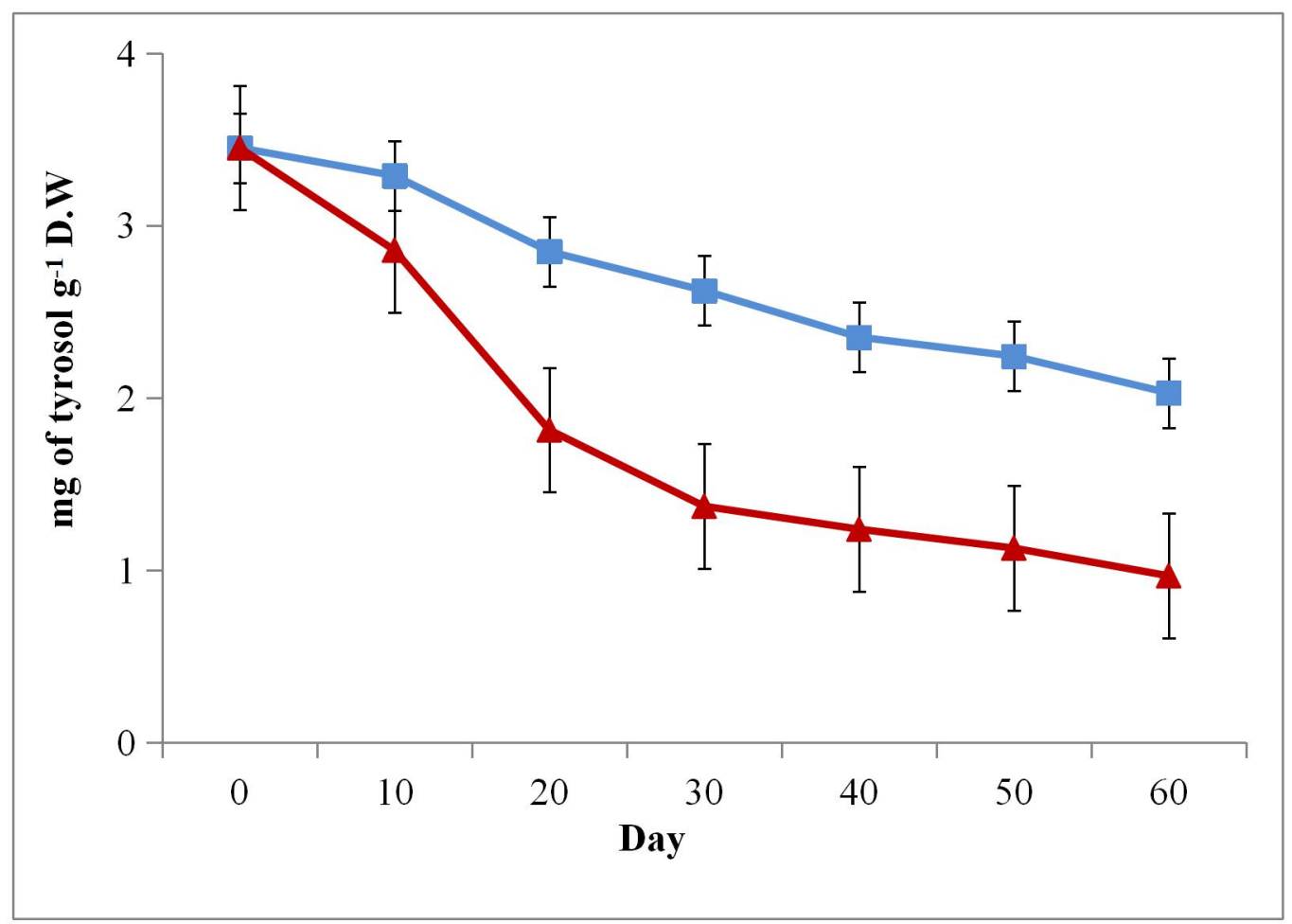

Figure 3: Changes in phenols' concentration with unacclimated $(--)$ and acclimated $(-\mathbf{r})$ earthworms during vermicomposting experiments. Vertical bars indicate standard deviation.

\section{Conclusion}

The results of this work confirm that acclimatization of Eisenia andrei allows a higher reproductive rate and a higher rate of OMWW detoxification than unacclimated earthworms. The rate of phenols reduction (72\%) obtained with acclimatized earthworms demonstrates the positive effect of acclimatization. Although OMWW are a recalcitrant organic by-product for decomposition, acclimatization of earthworms can enhance their potential 
adaptation to high OMWW concentrations (80\%). Physico-chemical characteristics $\mathrm{pH}, \mathrm{EC}, \mathrm{C} / \mathrm{N}$ and phenols reduction rate obtained indicate a good level of maturation and stabilizationof vermicompost produced with acclimated earthworm.On the other hand, the decrease of enzyme activities at the end of vermicomposting could indicate a rapid tendency to stability of the vermicompost organic matter. Thus, the period requiredfor the acclimatization of earthworms must be adjusted thanks to concentrations of OMWW lower than their threshold concentrations to achieve an optimal achievement of vermicomposting process.

\section{Acknowledgements}

This research work was financially supported by PHC Toubkal TBK/15/03-Campus France $\mathrm{N}^{\circ} 32548 \mathrm{XH}$ project.

\section{References}

[1] Roig, A., Cayuela, M.L. and Sánchez-Monedero M. (2006). An overview on olive mill wastes and their valorisation methods. Waste management, 26, 960-969.

[2] Barbera, A., Maucieri, C., Cavallaro, V., Ioppolo, A. and Spagna, G. (2013). Effects of spreading olive mill wastewater on soil properties and crops, a review. Agricultural Water Management, 119, 43-53.

[3] IOOC. (2016). Market newsletter of international olive oil council. http://www.internationaloliveoil.org.

[4] Stasinakis, A.S., Elia, I., Petalas, A.V. and Halvadakis, C.P. (2008). Removal of total phenols from olive-mill wastewater using an agricultural by-product, olive pomace. Journal of Hazardous Materials, 160, 408-413.

[5] Ait Baddi, G., Alburquerque, J.A., Gonzálvez, J., Cegarra, J. and Hafidi, M. (2004). Chemical and spectroscopic analyses of organic matter transformations during composting of olive mill wastes. International Biodeterioration \& Biodegradation, 54, 39-44.

[6] El Hajjouji, H., Fakharedine, N., Ait Baddi, G., Winterton, P., Bailly, J., Revel, J. and Hafidi, M. (2007). Treatment of olive mill waste-water by aerobic biodegradation: an analytical study using gel permeation chromatography, ultraviolet- visible and Fourier transform infrared spectroscopy. Bioresource technology, 98, 3513-3520.

[7] Zenjari, B. and Nejmeddine, A. (2001). Impact of spreading olive mill wastewater on soil characteristics: laboratory experiments. Agronomie, 21, 749-755

[8] Kapellakis, I.E., Tsagarakis, K.P. and Crowther, J.C. (2008). Olive oil history, production and by-product management. Reviews in Environmental Science and Bio/Technology, 7, 1-26.

[9] Paraskeva, C., Papadakis, V., Tsarouchi, E., Kanellopoulou, D. and Koutsoukos, P. (2007). Membrane processing for olive mill wastewater fractionation. Desalination, 213, 218-229.

[10] Garg, V. and Gupta, R. (2011) Optimization of cow dung spiked pre-consumer processing vegetable waste for vermicomposting using Eisenia fetida. Ecotoxicology and environmental safety, 74, 19-24

[11] Yadav, K.D., Tare, V. and Ahammed, M.M. (2011). Vermicomposting of source-separated human faeces by Eisenia fetida: effect of stocking density on feed consumption rate, growth characteristics and vermicompost production. Waste management, 31 , 1162-1168.

[12] Melgar, R., Benitez, E. and Nogales, R. (2009). Bioconversion of wastes from olive oil industries by vermicomposting process using the epigeic earthworm Eisenia andrei. Journal of Environmental Science and Health, Part B.44, 488-495.

[13] Sharma, S., Pradhan, K. Satya, S. and Vasudevan, P. (2005). Potentiality of earthworms for waste management and in other uses-A review. The Journal of American Science, 1, 4-16.

[14] Bouché, M.B. (1972). Lombriciens de France: écologie et systématique. Annales de Zoologie Ecologie Animale, INRA Editions, Paris.

[15] Dominguez, J. (2004). State-of-the-Art and New Perspectives on Vermicomposting Research. In: CRC Press, Ed., Earthworm ecology, Edwards C., Boca Raton, 401-424.

[16] Ndegwa, P.M., Thompson, S.A. and Das, K.C. (2000). Effects of stocking density and feeding rate on vermicomposting of biosolids. Bioresource technology, 71(1), 5-12.

[17] Edwards, C.A. (1998) The use of earthworms in the breakdown and management of organic wastes. In: CRC Press, Ed., Earthworm Ecology, C.A. Edwards., Boca Raton Florida, 327-354.

[18] Ganesh, P.S., Gajalakshmi, S. and Abbasi, S.A. (2009) Vermicomposting of the leaf litter of acacia (Acacia auriculiformis): Possible roles of reactor geometry, polyphenols, and lignin. Bioresource technology, 100, 1819-1827.

[19] Suthar, S. (2008a). Bioremediation of aerobically treated distillery sludge mixed with cow dung by using an epigeic earthworm Eisenia fetida. The Environmentalist, 28, 76-84. 
[20] Mekki, A., Dhouib, A. and Sayadi, S. (2006). Changes in microbial and soil properties following amendment with treated and untreated olive mill wastewater. Microbiological Research, 161, 93-101.

[21] Wang, P., Changa, C., Watson, M., Dick, W., Chen, Y. and Hoitink, H. (2004). Maturity indices for composted dairy and pig manures. Soil Biology and Biochemistry, 36, 767-776.

[22] Sánchez-Monedero, M., Roig, A. Paredes, C. and Bernal, M. (2001). Nitrogen transformation during organic waste composting by the Rutgers system and its effects on $\mathrm{pH}, \mathrm{EC}$ and maturity of the composting mixtures. Bioresource technology, 78, 301-308.

[23] Benitez, E., Nogales, R., Elvira, C., Masciandaro, G. and Ceccanti, B. (1999). Enzyme activities as indicators of the stabilization of sewage sludges composting with Eisenia foetida. Bioresource technology, 67, 297-303.

[24] Tiquia, S. and Tam, N. (2000). Co-composting of spent pig litter and sludge with forced-aeration. Bioresource technology, 72, $1-7$.

[25] Benito, M., Masaguer, A., Moliner, A., Arrigo, N. and Palma, R.M. (2003). Chemical and microbiological parameters for the characterisation of the stability and maturity of pruning waste compost. Biology and Fertility of Soils, 37, 184-189.

[26] Shi, Q-W., Liu, Q., Rong, X-M., Xie, G-X., Peng, J-W., Yu, Y-L., Zhang, Y-P. and Chen, X. (2006). Effects of different microbial agents on fermentation of rice straw in composting. Journal-Hunan Agricultural University, 32, 264.

[27] Dias, B.O., Silva, C.A., Higashikawa, F.S., Roig, A. and Sánchez-Monedero, M.A. (2010). Use of biochar as bulking agent for the composting of poultry manure: effect on organic matter degradation and humification. Bioresource technology, 101,1239-1246.

[28] Tognetti, C., Mazzarino, M.J. and Laos, F. (2007). Cocomposting biosolids and municipal organic waste: effects of process management on stabilization and quality. Biol. Fert Soils, 43, 387-397.

[29] Plaza, C., Nogales, R., Senesi, N., Benitez, E. and Polo, A. (2008). Organic matter humification by vermicomposting of cattle manure alone and mixed with two-phase olive pomace. Bioresource technology, 99, 5085-5089.

[30] Asses, N., Farhat, A., Cherif, S., Hamdi, M. and Bouallagui, H. (2018). Comparative study of sewage sludge co-composting with olive mill wastes or green residues: Process monitoring and agriculture value of the resulting composts. Process Safety and Environmental Protection, 114, 25-35.

[31] Lim, S.L., Wu, T. Sim, E.Y.S., Lim, P.N. and Clarke, C. (2012). Biotransformation of rice husk into organic fertilizer through vermicomposting. Ecological Engineering, 41, 60-64.

[32] Gunadi, B. and Edwards, C.A. (2003). The effects of multiple applications of different organic wastes on the growth, fecundity and survival of Eisenia fetida (Savigny) (Lumbricidae). Pedobiologia, 47, 321-329.

[33] Mitchell, A. (1997). Production of Eisenia fetida and vermicompost from feed-lot cattle manure. Soil Biology and Biochemistry, 29, 763-766.

[34] Alburquerque, J.A., Gonzálvez, J., García, D. and Cegarra, J. (2006). Measuring detoxification and maturity in compost made from "alperujo", the solid by-product of extracting olive oil by the two-phase centrifugation system. Chemosphere, 64, $470-477$.

[35] Kumar, M., Ou, Y. and Lin, J. (2010). Co-composting of green waste and food waste at low C/N ratio. Waste management, 30(4), 602-609.

[36] Mustin, M. (1987). Le compost: Gestion de la matière organique, Editions François Dubusc. Paris.

[37] Bishop, P.L. and Godfrey, C. (1983). Nitrogen transformations during sludge composting. Biocycle, $24,34-39$.

[38] Golueke, C.G. (1992). Bacteriology of composting. Biocycle, 33, 55-57.

[39] Ndegwa, P.M. and Thompson, S. (2000). Effects of C-to-N ratio on vermicomposting of biosolids. Bioresource technology, 75, $7-12$.

[40] Allison, F.E. (1973). Soil organic matter and its role in crop production. Elsevier scientific publishing company,Washington, USA.

[41] Grigatti, M., Ciavatta, C. and Gessa, C. (2004). Evolution of organic matter from sewage sludge and garden trimming during composting. Bioresource technology, 91, 163-169.

[42] arkin, T.B. and Berry, E.C. (1999). Microbial nitrogen transformations in earthworm burrows. Soil Biology and Biochemistry, $31,1765-1771$.

[43] Suthar, S. (2008b). Development of a novel epigeic-anecic-based polyculture vermireactor for efficient treatment of municipal sewage water sludge. International Journal of Environment and Waste Management, 2, 84-101.

[44] Galliou, F., Markakis, N., Fountoulakis, M.S., Nikolaidis, N. and Manios, T. (2018). Production of organic fertilizer from olive mill wastewater by combining solar greenhouse drying and composting. Waste Management, 75, 305-311.

[45] Madani, M., Aliabadi, M., Nasernejad, B., Kermanj, R.A. and Kestioglu, K. (2015). Treatment of olive mill wastewater using physico-chemical and Fenton process. Desalin Water Treatment, 53, 2031-2040. 